\title{
Tocilizumab efficacy in COVID-19 patients is associated with respiratory severity-based
}

\section{stages}

Melchor Alvarez-Mon MD, ${ }^{1,2,3,4} *$, Angel Asunsolo ${ }^{3,5,6} *$, José Sanz ${ }^{2,7}$, Benjamin Muñoz ${ }^{2,7}$, José Alberto Arranz-Caso ${ }^{2,7}$, Maria Novella Mena ${ }^{7}$, Cristina Hernández-Gutiérrez ${ }^{7}$, Jorge Navarro $^{7}$, Maria Cristina Lozano Duran ${ }^{7}$, Juan Arévalo Serrano ${ }^{7}$, Rocío Henche Sanchez ${ }^{7}$ Lara Bravo Quiroga ${ }^{8}$, Julio Flores Segovia ${ }^{8}$, Marta Garcia Sanchez ${ }^{7}$, Aida Gutierrez Garcia ${ }^{7}$, Ana Pérez ${ }^{1,2}$, Marta Herrero ${ }^{9}$, Nieves Plana ${ }^{3,10}$, Daniel Troncoso ${ }^{10}$, Gorjana Rackov ${ }^{11}$, Carlos Martinez-A ${ }^{11}$ and Dimitrios Balomenos ${ }^{11, * \S}$, for The Medicine-COVID19 HUPA group.

1. Internal Medicine Service and Rheumatology-Autoimmunity Service. "Príncipe de Asturias" University Hospital. Alcala de Henares, Madrid. Spain; 2. Department of Medicine and Medical Specialties. Alcala University. Madrid. Spain; 3. Ramón y Cajal Health Research Institute; 4. Ciber HyD. 5. Department of Surgery and Medical Social Sciences. Alcala University. Madrid. Spain; 6. Department of Epidemiology \& Biostatistics. Graduate School of Public Health and Health Policy, City University of New York, New York, NY, United States; 7. Internal Medicine Service "Príncipe de Asturias" University Hospital. Alcala de Henares, Madrid. Spain; 8. Respiratory Medicine Service "Príncipe de Asturias" University Hospital. Alcala de Henares, Madrid. Spain; 9. Pharmacy Service. "Príncipe de Asturias" University Hospital. Alcala de Henares, Madrid. Spain; 10. Preventive Medicine Service. “Príncipe de Asturias” University Hospital. Alcala de Henares, Madrid. Spain; 11. Department of Immunology and Oncology. National Center for Biotechnology. Spanish National Research Council/CSIC, Madrid. Spain

*Drs. M. Alvarez-Mon, A. Asunsolo and D. Balomenos contributed equally to this article. 
${ }^{\S}$ Corresponding author: Dr. D Balomenos.

Tel (+34) 915855449

Fax (+34) 913720493

email: dbalomenos@cnb.csic.es

Key words: tocilizumab, COVID-19, disease-stage, ARDS, immunomodulator

Running Title: Tocilizumab in COVID-19 severity stages

\section{Major Findings:}

Tocilizumab shows variable effectiveness depending on COVID-19 clinical respiratory severity (CRS) stages that could hinder analysis of its overall efficacy. Treatment suggested no effect in mild/moderate CRS1 patients, but led to a remarkable benefit in moderate/severe CRS2 patients, implying tocilizumab efficacy in non-ICU-admitted patients. In general, CRS classification emerges as an essential confounding factor in evaluating tocilizumab efficacy in broad-ranged patient severity studies.

\section{Author contributions:}

MAM, DB and CM conceived the main idea. MAM, AA and DB designed the study and analyzed results. DB wrote the manuscript and supervised the data. MAM and AA contributed in writing the manuscript and supervised the data. AA performed statistical analyses. GR analyzed the data and contributed in figure and table elaboration. All other authors supervised treatment of patients and obtained and recorded clinical data. 
medRxiv preprint doi: https://doi.org/10.1101/2021.03.04.21252167; this version posted March 9, 2021. The copyright holder for this preprint (which was not certified by peer review) is the author/funder, who has granted medRxiv a license to display the preprint in perpetuity.

It is made available under a CC-BY-NC-ND 4.0 International license .

\section{ABSTRACT (351 words)}

Background: Tocilizumab treatment is investigated, and effectiveness in ICU-admitted COVID-19 patients has been reported. Although controversy exists regarding the efficacy of tocilizumab treatment, it has been suggested that tocilizumab might show positive results depending on patient severity status. We examined an association between tocilizumab and distinct disease severity stages.

Methods and Findings: From March 3 to March 23 2020, 494 consecutively admitted COVID-19 patients received tocilizumab or standard treatment alone. Data were obtained retrospectively. Clinical respiratory severity (CRS) stages were defined by patient oxygenation status and were also associated to scores of WHO clinical progression scale. We categorized patients in three stages, mild/moderate $\mathrm{CRS} 1\left(\mathrm{FiSpO}{ }_{2}<0.35\right.$; WHO score 5), moderate/severe CRS2 $\left(\mathrm{FiO}_{2}=0.5 /\right.$ high flow mask; WHO score 6) and severe/critical CRS3 $\left(\mathrm{FiO}_{2}<80 \% /\right.$ high flow/prone position or mechanical ventilation; score $\left.>6\right)$. The primary outcome was the composite of death or ICU admission in patients of stages CRS1, CRS2, and CRS3, as well as in total patients. We also addressed mortality alone in total patients. KaplanMaier curves, Cox proportional regression and inverse probability weighting marginal structural models were used. We conducted the study from March 3 to April 72020 with broad-ranged severity patients; 167 tocilizumab-treated and 327 untreated. CRS1 patients showed no apparent benefit after treatment, while the risk of the primary outcome was greatly reduced in $\mathrm{CRS} 2$ treated participants $((\mathrm{HR}=0.22 ; 95 \% \mathrm{CI}(0.16-0.44))$. Moreover, tocilizumab treatment was associated with significantly decreased CRS2 patient proportion that reached the outcome compared to non-treated controls $(27.8 .0 \%$ vs. $65.4 \%$; $<0.001)$. Severe/critical CRS3 patients, also showed benefit after treatment $(\mathrm{HR}=0.38 ; 95 \% \mathrm{CI}(0.16-90))$, although not as robust as was that of CRS2 treated individuals. Tocilizumab was associated with reduced outcome risk in total patients $(\mathrm{HR}=0.42 ; 95 \% \mathrm{CI}(0.26-0.66))$ after CRS adjustment, 
but not if CRS classification was not accounted as confounding factor $(\mathrm{HR}=1.19 ; 95 \% \mathrm{CI}$

(0.84-1.69)). The outcome of mortality alone upon tocilizumab treatment was significant $(\mathrm{HR}=0.58 ; 95 \% \mathrm{CI}(0.35-0.96))$ after accounting for CRS classification.

Conclusions: Tocilizumab treatment is associated with reduced COVID-19 escalation in CRS2 patients, suggesting efficacy in moderate/severe non-ICU-admitted patients. CRS classification could represent an essential confounding factor in evaluating tocilizumab in studies of broad-ranged severity patients. 
medRxiv preprint doi: https://doi.org/10.1101/2021.03.04.21252167; this version posted March 9, 2021. The copyright holder for this preprint (which was not certified by peer review) is the author/funder, who has granted medRxiv a license to display the preprint in perpetuity.

It is made available under a CC-BY-NC-ND 4.0 International license .

\section{INTRODUCTION}

2 Severe acute respiratory syndrome coronavirus-2 (SARS-CoV-2), has spread worldwide

3 and is considered pandemic. Approximately $10-15 \%$ of patients, primarily older individuals

$4(1,2)$ (> 60 years of age) develop severe COVID-19 (Coronavirus disease 2019) pneumonia

5 that requires hospitalization and/or intensive care unit (ICU) admission and suffer high

6 mortality rates.

7 COVID-19 progression is related to cytokine storm linked hyperinflammation, driving 8 acute respiratory distress syndrome (ARDS), multiple organ failure and sepsis [3].

9 Hyperinflammation and elevated cytokine and chemokine levels are associated with increased risk of death in patients with COVID-19 [4], providing rationale for immunomodulatory

11 therapy [5,6]. Tocilizumab is a humanized monoclonal antibody that binds the soluble and 12 membrane bound IL-6 receptor [7]. It has been approved for autoimmune disease treatment 13 [8] and for CAR-T-therapy-related cytokine release syndrome $[9,10]$.

14 Initial pilot studies suggested a possible tocilizumab effect in COVID-19 treatment [11].

15 More recent cohort studies showed effectiveness of tocilizumab in severe/critical patients 16 [12-15], while clinical trials established no effect of tocilizumab in early stage patients 17 (mild/moderate) [16-18]. Some of the trials with negative results have been criticized [19,20]

18 and limitations to these studies have been emphasized, generating controversy about the effect

19 of tocilizumab [21]. Preliminary data from the COVACTA clinical trial [22] raised important 20 questions about the efficacy of tocilizumab in reducing the duration of hospital and ICU stay.

21 However, the EMPACTA trial suggested tocilizumab efficacy in delaying disease escalation

22 [23]. Recently, preliminary data from the REMAP-CAP trial reported benefit in the most 23 severely ill patients [24], while the RECOVERY trial demonstrated that tocilizumab reduces 24 mortality in patients receiving corticosteroids [25]. Recent meta-analysis found an association 
medRxiv preprint doi: https://doi.org/10.1101/2021.03.04.21252167; this version posted March 9, 2021. The copyright holder for this preprint (which was not certified by peer review) is the author/funder, who has granted medRxiv a license to display the preprint in perpetuity.

It is made available under a CC-BY-NC-ND 4.0 International license.

25 between tocilizumab and improved outcomes in moderate and severe patients (non-ICU), as

26 well as in critically ill patients (ICU) [26].

27 We conducted a retrospective cohort study of 494 consecutively admitted COVID-19

28 patients that were classified in stages according to their Clinical Respiratory Severity (CRS).

29 We provide evidence that tocilizumab is associated with reduced disease escalation in a CRS-

30 depending manner, and that CRS classification is a critical confounding factor to be

31 accounted for upon evaluation of tocilizumab's therapeutic potential in the global patient

32 population.

33 
medRxiv preprint doi: https://doi.org/10.1101/2021.03.04.21252167; this version posted March 9, 2021. The copyright holder for this preprint (which was not certified by peer review) is the author/funder, who has granted medRxiv a license to display the preprint in perpetuity.

It is made available under a CC-BY-NC-ND 4.0 International license .

\section{METHODS}

\section{Patients}

Patients positive for SARS-Cov-2 from March 3 to March 232020 who met the conditions of (1) respiratory rate $\geq 30$ breaths/min, (2) $\mathrm{SpO}_{2} \leq 94 \%$ while breathing ambient air, and (3) thorax X-ray with opacities, were included in the study, as defined by the Diagnosis and Treatment Protocol for Novel Coronavirus Pneumonia (6th interim edition) [27].

We obtained demographic data, as well as comorbidities (cancer, diabetes mellitus, cardiovascular disease, chronic kidney disease, among others) from electronic health records. We registered clinical symptoms, time of disease onset and laboratory and radiological data. Standard treatment (ST) included lopinavir/ritonavir, hydroxychloroquine, IFN- $\beta$ and azithromycin in case of secondary infections (Supplementary Table 1). IFN- $\beta$ administration depended on the comorbidity extent and on age (> 65 years old). Two doses of IFN- $\beta$ (at admission and at $48 \mathrm{~h}$, discontinued then after due to apparent patient worsening) were given to 89 tocilizumab-treated patients and to 90 controls. At admission, patients received oxygen support though low-flow nasal cannula to maintain $\mathrm{SpO}_{2}>90 \%$. Patients with increased oxygen needs were switched to high-flow oxygen mask (Venturi mask up to $50 \% \mathrm{FiO}_{2}$ ). Mechanical ventilation (MV) was provided only to ICU admitted patients. Considering the critical situation at the hospital, access to ICU was limited and patients that would otherwise be admitted to ICU were treated on the ward.

\section{Study plan}

We carried out an open cohort study from March 3 to April 7 2020, including patients that received tocilizumab (Supplementary Table 1) in addition to ST or only ST.

Patient selection for tocilizumab treatment depended on the study design, the availability of tocilizumab and on ethical decisions, based on patient evolution during the time between 
medRxiv preprint doi: https://doi.org/10.1101/2021.03.04.21252167; this version posted March 9, 2021. The copyright holder for this preprint (which was not certified by peer review) is the author/funder, who has granted medRxiv a license to display the preprint in perpetuity.

It is made available under a CC-BY-NC-ND 4.0 International license .

60 admission and treatment. ST was given to all patients of both groups upon admission. Patients

61 received tocilizumab after four-day observation (60\% of patients at 4 day; for all patients

62 mean $\pm \mathrm{SD}, 4.06 \pm 0.099)$. Initial observation depended on $\mathrm{SpO}_{2}$ levels and clinical evaluation.

63 Patients with rapidly increasing oxygen needs or radiological or clinical worsening were

64 prioritized to receive tocilizumab.

65 The study was approved by the institutional review board of the University Hospital Prince

66 of Asturias (HUPA0406/20). All patients provided informed consent before starting

67 treatment.

68 Study definitions

69 The study was designed to examine the effect of tocilizumab in patients of wide-ranged 70 severity separated in groups. After data collection we classified patients according to 71 oxygenation needs $\left(\mathrm{FiO}_{2}\right)$ at the time of treatment and considering the WHO clinical 72 progression scale [28], after its publication. We defined three clinical respiratory severity 73 (CRS) stages; (1) CRS1; mild/moderate patients on low-flow oxygen supplementation $74 \mathrm{FiO} 2 \leq 0.35$, WHO score 5, (2) CRS2; moderate/severe patients on high-flow oxygen supplementation $\mathrm{FiO} 2=0.50$, WHO score 6, (3) CRS3; severe/critical patients on high-flow oxygen supplementation $\mathrm{FiO} 2=0.50$, prone position, or on $\mathrm{MV}$ in $\mathrm{ICU}$ at the day of treatment,

77 WHO score $>6$. CRS3 patients were considered critical not only because of the critical respiratory status but also due to the severity of CRS3 patients which showed much higher 79 proportions of death or ICU admission compared to CRS2 individuals.

80 Initially, patient severity was considered on the basis of $\mathrm{SpO}_{2}$ measurements on ambient 81 air and/or after low-flow oxygen supply during initial observation (24 hours or less). The 82 groups were defined by patients with $\mathrm{SpO}_{2}>90 \%$ (corresponding to $\mathrm{CRS} 1$ ), $80 \%<\mathrm{SpO}_{2}<90 \%$ 83 (corresponding to $\mathrm{CRS} 2$ ), and $\mathrm{SpO}_{2}<80 \%$ (corresponding to CRS3). By the end of the study 84 we considered that we had enough patients in order to proceed to statistical analysis. This 
medRxiv preprint doi: https://doi.org/10.1101/2021.03.04.21252167; this version posted March 9, 2021. The copyright holder for this preprint (which was not certified by peer review) is the author/funder, who has granted medRxiv a license to display the preprint in perpetuity.

It is made available under a CC-BY-NC-ND 4.0 International license .

85 characterization was based on reports, showing that ARDS patients with oxygen

86 supplementation and $\mathrm{SpO}_{2}<90 \%$ show increased mortality, compared to patients with

$87 \mathrm{SpO}_{2}>90 \%$ [29]. Also, COVID patients with dyspnea (frequently manifested at $\mathrm{SpO}_{2}<90 \%$ )

88 show propensity for disease escalation [30]. Furthermore, there is an association of

$89 \mathrm{SpO}_{2}<80 \%$ patients with severe hypoxemia and increased risk of developing hypoxia [31-

$9033]$.

91 Outcomes of the study

92 The primary outcome of the study was composite of death or admission to the ICU after

93 tocilizumab treatment of CRS1, CRS2 and CRS3 stage patients, as well as of the total patient

94 population.

95 In the secondary analysis death alone was conducted as endpoint, counting all in-hospital 96 deaths of the patients. Deaths that occurred after ICU admission were available from hospital 97 records and were also included in the analysis.

98 Statistical analysis

99 Descriptive statistics were used to summarize the data; age and days between onset of 100 symptoms and hospital admission were reported as means and standard deviations, and 101 laboratory results are reported as medians and interquartile ranges (IQR). Categorical 102 variables were summarized as counts and percentages. Associations between patient 103 characteristics and tocilizumab treatment were evaluated; in the case of categorical variables,

104 we used a Pearson's chi-squared or Fisher exact test, and in the case of quantitative variables, 105 Student's t test, the Mann-Whitney's U test, or Wilcoxon's test, as appropriate. No imputation 106 was made for missing data and no sample size calculations were performed.

107 We conducted a Cox proportional regression model with fixed covariates of patients from 108 the day of treatment to the day of ICU admission or death for the different patient CRS stages 109 adjusting for age, sex and IFN- $\beta$ treatment. For total patients Cox analysis was also adjusted 
medRxiv preprint doi: https://doi.org/10.1101/2021.03.04.21252167; this version posted March 9, 2021. The copyright holder for this preprint (which was not certified by peer review) is the author/funder, who has granted medRxiv a license to display the preprint in perpetuity.

It is made available under a CC-BY-NC-ND 4.0 International license .

110 for CRS stages (CRS1, CRS2, CRS3). The start date of the follow-up was the day they

111 received the medication. There were no differences in censorship for hospital discharge in

112 both treated and untreated groups. We tested the proportional-hazards assumption on the basis

113 of Schoenfeld residuals. This model may produce biased effect estimates when there are time-

114 dependent confounders, which are affected by previous treatment or exposure. In this study,

115 the CRS status is both a time-dependent confounder of the causal effect of the treatment on

116 survival and is affected by past treatment $[34,35]$. We thus conducted a marginal structural

117 model to estimate the causal effect of tocilizumab on the severe COVID-19 patients. We

118 carried out an unweighted pooled logistic regression, treating each person-day as an

119 observation (model 2). We fitted a pooled logistic regression weighted by the inverse-

120 probability-of-treatment (IPWT). Each patient in the above logistic model received a time-

121 varying weight inversely proportional to the estimated probability of having his/her own

122 observed history of tocilizumab initiation, as described [34,36]. This weighting means that

123 observations on the same subject will correlate, we therefore used the robust standard errors

124 for clustering. Follow-up start day was the day of admission.

125 All models were adjusted for CRS stages (unless otherwise mentioned), sex, age, and

126 IFN- $\beta$ treatment. All statistical analyses were performed using STATA v14 SE or SPSSv26.

127

128 RESULTS

129 We included 494 consecutively admitted patients, positive for SARS-CoV-2 and COVID-

13019 pneumonia. 167 patients received tocilizumab, while 327 did not (Figure 1). Age, gender

131 distribution and frequency of comorbidities were similar for both groups (Table 1). Disease

132 was classified in stages CRS1, CRS2 and CRS3 according to severity. Due to clinical

133 selection, CRS2 and CRS3 stages had higher proportions of treated than untreated patients

134 (Table 1). Occurrence of secondary infections was minimal $(<5 \%)$ by both patient groups, and

135 no opportunistic infections were recorded. 
medRxiv preprint doi: https://doi.org/10.1101/2021.03.04.21252167; this version posted March 9, 2021. The copyright holder for this preprint (which was not certified by peer review) is the author/funder, who has granted medRxiv a license to display the preprint in perpetuity.

It is made available under a CC-BY-NC-ND 4.0 International license .

\section{CRS stage characteristics}

137 CRS definition was validated after data collection. First, age, sex and comorbidities were 138 found balanced within the CRS1, CRS2 and CRS3 stages (Table 2), indicating no bias in CRS

139 definition. Second, CRP and HDL levels increased according to disease severity

140 (CRS1<CRS2<CRS3), while lymphocyte concentrations were inversely correlated to this

141 pattern (Table 2). These results support the CRS stage definition, since inflammation-

142 associated factors are associated to COVID-19 severity [3], and hypoxemia could exacerbate

143 inflammatory progression [37]. Third, $\mathrm{SpO}_{2}$ levels at baseline and after oxygen

144 supplementation followed the CRS stage severity graduation (Table 2). $\mathrm{SpO}_{2} / \mathrm{FiO}_{2}$ ratios were

145 obtained for CRS1, CRS2 and CRS3 patients on the basis of $\mathrm{SpO}_{2}$ limit values, as $\mathrm{FiO}_{2}$ was

$146 \leq 35 \%$ for CRS1, while all CRS2 and CRS3 patients received $\mathrm{FiO}_{2}=50 \%$ or $\mathrm{MV}$ after ICU

147 admission (Table 2). CRS stages were correlated to ARDS development, since $\mathrm{SpO}_{2} / \mathrm{FiO}_{2}$

148 cutoffs of $100<200<300$ predict ARDS [38]. Thus, for $\mathrm{CRS} 1, \mathrm{SpO}_{2} / \mathrm{FiO}_{2}$ reflected lower

149 probability for ARDS and higher probability for CRS2 and CRS3 stages. Equivalent

$150 \mathrm{PaO}_{2} / \mathrm{FiO}_{2}$ ratios were estimated from $\mathrm{SPO}_{2} / \mathrm{FiO}_{2}$ values [39] (Table 2) and were cautiously

151 considered, since they were not directly obtained. Thus, CRS1 stage corresponded to mild,

152 CRS2 to moderate and CRS3 to severe ARDS, according to established criteria [40,41].

153 Based on the above results, we considered the disease of CRS1 as mild/moderate, CRS2 as

154 moderate/severe and CRS3 as severe/critical, since at baseline CRS3 patients received high-

155 flow oxygen or MV after ICU admission.

\section{Outcomes}

157 Analysis of the tocilizumab effect on the primary outcome for CRS1, CRS2 and CRS3

158 patients included Kaplan-Meier survival curves and multivariate Cox regression after

159 adjusting for age, sex and the IFN- $\beta$ impact. In CRS1 patients, tocilizumab did not show an

160 apparent effect in lowering the outcome risk $(\mathrm{HR}=0.7695 \% \mathrm{CI}(0.34,1.70))$ (Figure $2 \mathrm{~A})$. 
medRxiv preprint doi: https://doi.org/10.1101/2021.03.04.21252167; this version posted March 9, 2021. The copyright holder for this preprint (which was not certified by peer review) is the author/funder, who has granted medRxiv a license to display the preprint in perpetuity.

It is made available under a CC-BY-NC-ND 4.0 International license .

161 Although the percentage of CRS1 patients that reached the endpoint was reduced $(23.5 \%$

162 untreated vs. $15.6 \%$ treated), the results lacked significance (Figure 2B). On the other hand,

163 the data show significantly delayed outcome in tocilizumab treated CRS2 and CRS3 patients

164 (Figure 2A). A benefit was probable to occur for CRS2 treated patients (HR=0.22 95\% CI

$165(0.16,0.44))$ and for CRS3 patients $(\mathrm{HR}=0.3895 \%$ CI $(0.16,0.90))$ (Figure 2A). Moreover,

166 our data indicated that tocilizumab could significantly reduce the proportion of CRS2 patients

167 that reached the endpoint $(65.4 \%$ untreated vs. treated $27.8 \%$ patients; $\mathrm{p}<0.001)$ (Figure $2 \mathrm{~B})$.

168 Such reduction appeared to be not significant for treated CRS3 patients, possibly due to the

169 low number of untreated patients in CRS3. These data suggest that tocilizumab could be most

170 effective when administered to CRS2 stage patients.

171 In the entire treated population, tocilizumab greatly reduced CRP levels and elevated

172 lymphocyte concentrations $48 \mathrm{~h}$ post-treatment (Supplementary Table 2), corroborating

173 previous reports [3]. To evaluate the effect of tocilizumab in all patients with respect to the

174 composite endpoint, we conducted a multivariate Cox proportional-hazards analysis and

175 accounted for CRS stage classification as confounding variable, in addition to age, sex and

176 the impact of IFN- $\beta$. We showed an association between tocilizumab treatment and reduced

177 risk of reaching the composite outcome (Figure 3A and Table 3, model 1).

178 In secondary analysis, Cox evaluation including the above adjustments, also indicated

179 reduced risk for mortality alone after tocilizumab treatment, considering all hospital deaths

$180 \quad(\mathrm{HR}=0.5895 \% \mathrm{CI}(0.35,0.96))$.

181 Disease status of COVID-19 patients was a decisive confounding factor to be accounted 182 for regression analysis for our broad-ranged population. Notably, Cox analysis, that did not 183 account for CRS stages but included all other mentioned confounding parameters, showed no

184 effect of tocilizumab in reducing the risk for the composite outcome (HR=1.19 CI 95\% (0.84-

185 1.69)) (Figure 3B and Supplementary Table 3). 
medRxiv preprint doi: https://doi.org/10.1101/2021.03.04.21252167; this version posted March 9, 2021. The copyright holder for this preprint (which was not certified by peer review) is the author/funder, who has granted medRxiv a license to display the preprint in perpetuity.

It is made available under a CC-BY-NC-ND 4.0 International license .

In addition to Cox based evaluation in all patients, we conducted an unweighted pooled logistic regression analysis for death or ICU admission and a weighted pooled logistic regression by IPWT (Table 3, models 2,3 ). These models indicated that tocilizumab relates with a reduced risk in patient mortality or ICU admission, and that age, but not sex, significantly increased the risk for the end event. The risk for the outcome was significantly

191 increased by IFN- $\beta$ treatment, at least by model 1 . Importantly, the three models confirmed

192 that the patients' CRS stage is a significant risk factor for death or ICU admission and 193 confirmed that the CRS2 that CRS3 patients, as compared to CRS1, present a significantly higher probability of reaching the end event.

\section{DISCUSSION}

197 In this retrospective cohort study we tested tocilizumab efficacy in COVID-19 patients

198 according to their clinical respiratory severity, and we concluded that: (1) tocilizumab had no 199 apparent effect in reducing the risk of composite outcome (death or ICU admission)

200 mild/moderate CRS1 patients; (2) the benefit from tocilizumab treatment was particularly 201 pronounced in patients categorized as CRS2 (moderate/severe) and to a lesser extent in CRS3

202 patients (severe/critical); (3) analysis of total patients as a single population required CRS 203 stage adjustment to show beneficial effect for tocilizumab.

204 Measuring $\mathrm{SpO}_{2}$ is not invasive and was easier to perform under the critical conditions of 205 the COVID-19 pandemic. $\mathrm{SpO}_{2}$-based CRS stage classification is reinforced by another study 206 showing that after oxygen supplementation, $\mathrm{SpO}_{2}>90 \%$ predicted survival, while $\mathrm{SpO}_{2}<90 \%$ 207 levels were associated with COVID-19 escalation [42]. Results obtained during the study, 208 such as CRP levels, $\mathrm{SpO}_{2} / \mathrm{FiO}_{2}$ and estimated $\mathrm{PaO}_{2} / \mathrm{FiO}_{2}$ ratios further validated CRS stage 209 classification and corroborated the stage severity CRS1<CRS2<CRS3. Further refining of 
medRxiv preprint doi: https://doi.org/10.1101/2021.03.04.21252167; this version posted March 9, 2021. The copyright holder for this preprint (which was not certified by peer review) is the author/funder, who has granted medRxiv a license to display the preprint in perpetuity.

It is made available under a CC-BY-NC-ND 4.0 International license .

210 CRS stages using additional oxygenation, inflammatory and clinical parameters might aid in

211 optimizing prediction of the earliest point of tocilizumab delivery.

212 Current views on tocilizumab use suggest no effect on early stage hospitalized patients but

213 therapeutic benefit in severe/critical patients [43-45]. We found that tocilizumab did not

214 provide significant benefit on disease progression for mild/moderate CRS1 patients

215 (estimated $\mathrm{PaO}_{2} / \mathrm{FiO}_{2}>240 \mathrm{~mm} \mathrm{Hg}$ ). This concurs with randomized trials, which showed no

216 benefit after tocilizumab treatment in patients with mild/moderate disease severity

$217 \quad\left(200<\mathrm{PaO}_{2} / \mathrm{FiO}_{2}<300 \mathrm{~mm} \mathrm{Hg}\right)[16-18]$.

218 For CRS2 patients, multivariate Cox analysis showed an association between tocilizumab

219 treatment and reduced outcome (death or ICU) risk. The clearest risk reduction was detected

220 for CRS2 stage treated-patients (estimated $\mathrm{PaO}_{2} / \mathrm{FiO}_{2}<150 \mathrm{~mm} \mathrm{Hg}$ ), and this was further

221 confirmed by significantly decreased proportion of patients that reached the endpoint. These

222 results concurred with another study showing reduced risk of disease escalation in treated-

223 patients with $\mathrm{PaO}_{2} / \mathrm{FiO}_{2}<150 \mathrm{~mm} \mathrm{Hg}$ [46].

224 Our results suggested a greater tocilizumab effect in CRS2 compared to CRS3 stage

patients, supporting the view that tocilizumab increases effectiveness when delivered at

earlier disease stages $[45,47]$. This might be explained by more severe respiratory deficiency

in CRS3 compared to CRS2 patients. Effectiveness of tocilizumab in CRS3 stage is

corroborated by other studies focused on severe/critical patients, showing beneficial effects of

tocilizumab for patients on MV [48], or tocilizumab delivery two days after ICU admission

230 [45]. Finally, as CRS2 patients did not require ICU admission at baseline, tocilizumab

231 treatment could be an option for moderate/severe patients on high-flow oxygen supply.

232 When global patient population was considered, three models of regression analysis

233 showed that tocilizumab was associated with a reduced risk of the composite outcome, after

234 accounting for CRS stage classification as a confounding factor together with patient age, sex 
medRxiv preprint doi: https://doi.org/10.1101/2021.03.04.21252167; this version posted March 9, 2021. The copyright holder for this preprint (which was not certified by peer review) is the author/funder, who has granted medRxiv a license to display the preprint in perpetuity.

It is made available under a CC-BY-NC-ND 4.0 International license .

235 and other treatments. In addition, multivariate Cox regression analysis showed significantly

236 lowered risk in the case that mortality alone was the outcome.

237 Adjustment for CRS stages was decisive for the estimated therapeutic effect of tocilizumab

238 in all patients, since after excluding the CRS stage classification, as confounding variable,

239 tocilizumab benefit was no longer evidenced.

240 Preliminary data from clinical trials COVACTA and EMPACTA (19-20) that included

241 broad ranged patient populations, showed that tocilizumab was not as efficacious as in

242 observational studies that focused on advanced disease stages. The COVACTA study did not

243 meet the primary outcome, as tocilizumab did not reduce clinical worsening or mortality. The

244 wide-ranged severity of the patients could be a drawback, considering that the inefficacy of

245 tocilizumab in mild/moderate severity patients might have obscured relevant therapeutic

246 effects [44]. The EMPACTA trial [50] showed reduced risk of MV or death, but not of

247 mortality alone in tocilizumab-treated patients.

248 On the basis of our findings, we believe that future clinical studies could draw more

249 accurate conclusions by considering disease stage classification and including it as a

250 confounding factor in regression analyses.

251 Overall, using a single tocilizumab appears to be safe for the patients and does not increase

252 secondary infections, as shown by us and other studies [17,45,50]. Perhaps a second

253 consecutive tocilizumab delivery might result in increased secondary infections [12].

254 Our study has the following limitations. First, the study was performed in one hospital and 255 was not randomized as tocilizumab treatment was prioritized for worsening patients within 256 the same CRS stage. Second, CRS3 stage patient population did not get the support of MV 257 due to the near collapse conditions in Spain at the time of the study. Third, our study was not 258 blinded and therefore a bias for ICU admission could favor untreated patients; this limitation 
medRxiv preprint doi: https://doi.org/10.1101/2021.03.04.21252167; this version posted March 9, 2021. The copyright holder for this preprint (which was not certified by peer review) is the author/funder, who has granted medRxiv a license to display the preprint in perpetuity.

It is made available under a CC-BY-NC-ND 4.0 International license .

259 was minimized as analysis of overall hospital mortality as an endpoint showed benefit after

260 tocilizumab treatment.

261 The strengths of this study include the newly applied patient classification in CRS stages.

262 This later point is crucial since previous studies mostly found no tocilizumab effect when

263 considering patients of wide range disease severity. Several analyses were performed, with

264 consistent results across the models. Oxygen supplementation was uniform especially for the

265 CRS2 stage, as the vast majority of the patients were managed on the floor (i.e. not in the

266 ICU) on steady $\mathrm{FiO}_{2}$, avoiding the bias of oxygen supplementation in influencing the

267 outcome. Finally, although differences in tocilizumab efficacy have been suggested to depend

268 on disease stage, here we show this in a single study that encompassed three disease stages.

269 Conclusions

270 Tocilizumab shows variable efficacy, depending on three COVID-19 clinical respiratory

271 severity (CRS) stages. Treatment had no apparent benefit in CRS1 patients, but was

272 associated with a remarkable benefit in CRS2 patients, suggesting that tocilizumab could

273 target stages that did not require ICU care. These findings could contribute to define the

274 optimal point for treatment initiation. In general terms, our results indicate that the CRS-

275 associated efficacy of tocilizumab could eventually hinder evaluation of its therapeutic effect,

276 and suggest the possibility to consider CRS patient classification as a confounding factor in

277 analyzing the efficacy of tocilizumab. These conclusions could assist in designing and/or

278 interpreting randomized clinical trials. 
medRxiv preprint doi: https://doi.org/10.1101/2021.03.04.21252167; this version posted March 9, 2021. The copyright holder for this preprint (which was not certified by peer review) is the author/funder, who has granted medRxiv a license to display the preprint in perpetuity.

It is made available under a CC-BY-NC-ND 4.0 International license.

\section{Acknowledgements}

We thank Catherine Mark for editorial assistance. This work was partially supported by grants from the Fondo de Investigación de la Seguridad Social-Instituto de Salud Carlos III (PI18/01726), Spain. Programa de Actividades de I+D de la Comunidad de Madrid en Biomedicina (B2017/BMD-3804), Madrid, Spain. Instituto de Salud Carlos III CIBER Enfermedades hepáticas y Digestivas, Spain. Agencia Estatal de Investigación. SAF201680803-R. Medicina individualizada traslacional, en inflamación y cáncer. Comunidad de Madrid. B2017/BMD-3804, Spain (to: MAM, CMA and DB). GR holds Juan de la Cierva grant (Ministerio de Ciencia e Innovación). 
medRxiv preprint doi: https://doi.org/10.1101/2021.03.04.21252167; this version posted March 9, 2021. The copyright holder for this preprint (which was not certified by peer review) is the author/funder, who has granted medRxiv a license to display the preprint in perpetuity.

It is made available under a CC-BY-NC-ND 4.0 International license .

\section{REFERENCES}

279 1. Wu JT, Leung K, Bushman M, Kishore N, Niehus R, de Salazar PM, et al. Estimating

280 clinical severity of COVID-19 from the transmission dynamics in Wuhan, China. Nat

$281 \quad$ Med. 2020;26: 506-510. doi:10.1038/s41591-020-0822-7

282 2. Zhou M, Zhang X, Qu J. Coronavirus disease 2019 (COVID-19): a clinical update.

283 Front Med. 2020;2019. doi:10.1007/s11684-020-0767-8

284 3. Zhou F, Yu T, Du R, Fan G, Liu Y, Liu Z, et al. Clinical course and risk factors for

285 mortality of adult inpatients with COVID-19 in Wuhan, China: a retrospective cohort

286 study. Lancet. 2020;395: 1054-1062. doi:10.1016/S0140-6736(20)30566-3

287 4. Hue S, Beldi-Ferchiou A, Bendib I, Surenaud M, Fourati S, Frapard T, et al.

288 Uncontrolled Innate and Impaired Adaptive Immune Responses in Patients with

289 COVID-19 Acute Respiratory Distress Syndrome. Am J Respir Crit Care Med.

$290 \quad$ 2020;202: 1509-1519. doi:10.1164/rccm.202005-1885oc

291 5. Mehta P, McAuley DF, Brown M, Sanchez E, Tattersall RS, Manson JJ. COVID-19:

292 consider cytokine storm syndromes and immunosuppression. Lancet. 2020;395: 1033-

293 1034. doi:10.1016/S0140-6736(20)30628-0

294 6. Henderson LA, Canna SW, Schulert GS, Volpi S, Lee PY, Kernan KF, et al. On the

295 Alert for Cytokine Storm: Immunopathology in COVID-19. Arthritis Rheumatol.

296 2020;72: 1059-1063. doi:10.1002/art.41285

297 7. Michot JM, Albiges L, Chaput N, Saada V, Pommeret F, Griscelli F, et al.

298 Tocilizumab, an anti-IL-6 receptor antibody, to treat COVID-19-related respiratory

299 failure: a case report. Ann Oncol. 2020;31: 961-964.

$300 \quad$ doi:10.1016/j.annonc.2020.03.300

301 8. Kaneko Y, Kato M, Tanaka Y, Inoo M, Kobayashi-Haraoka H, Amano K, et al.

302 Tocilizumab discontinuation after attaining remission in patients with rheumatoid 
medRxiv preprint doi: https://doi.org/10.1101/2021.03.04.21252167; this version posted March 9, 2021. The copyright holder for this preprint (which was not certified by peer review) is the author/funder, who has granted medRxiv a license to display the preprint in perpetuity.

It is made available under a CC-BY-NC-ND 4.0 International license .

306

307

308

arthritis who were treated with tocilizumab alone or in combination with methotrexate:

Results from a prospective randomised controlled study (the second year of the SURPRIS. Ann Rheum Dis. 2018;77: 1268-1275. doi:10.1136/annrheumdis-2018213416

9. Le RQ, Li L, Yuan W, Shord SS, Nie L, Habtemariam BA, et al. FDA Approval Summary: Tocilizumab for Treatment of Chimeric Antigen Receptor T Cell-Induced Severe or Life-Threatening Cytokine Release Syndrome. Oncologist. 2018;23: 943 947. doi:10.1634/theoncologist.2018-0028

10. Zhang C, Wu Z, Li JW, Zhao H, Wang GQ. The cytokine release syndrome (CRS) of severe COVID-19 and Interleukin-6 receptor (IL-6R) antagonist Tocilizumab may be the key to reduce the mortality. Int J Antimicrob Agents. 2020; 105954. doi:10.1016/j.ijantimicag.2020.105954

11. Alzghari SK, Acuña VS. Supportive Treatment with Tocilizumab for COVID-19: A Systematic Review. J Clin Virol. 2020;127: 104380. doi:10.1016/j.jcv.2020.104380

12. Biran N, Ip A, Ahn J, Go RC, Wang S, Mathura S, et al. Tocilizumab among patients with COVID-19 in the intensive care unit: a multicentre observational study. Lancet Rheumatol. 2020;2: e603-e612. doi:10.1016/S2665-9913(20)30277-0

13. Jordan SC, Zakowski P, Tran HP, Smith EA, Gaultier C, Marks G, et al. Compassionate Use of Tocilizumab for Treatment of SARS-CoV-2 Pneumonia. Clin Infect Dis. 2020; 1-6. doi:10.1093/cid/ciaa812

14. Martínez-Sanz J, Muriel A, Ron R, Herrera S, Pérez-Molina JA, Moreno S, et al. Effects of tocilizumab on mortality in hospitalized patients with COVID-19: a multicentre cohort study. Clin Microbiol Infect. 2020. doi:10.1016/j.cmi.2020.09.021

15. Rodríguez-Baño J, Pachón J, Carratalà J, Ryan P, Jarrín I, Yllescas M, et al. Treatment with tocilizumab or corticosteroids for COVID-19 patients with hyperinflammatory 
medRxiv preprint doi: https://doi.org/10.1101/2021.03.04.21252167; this version posted March 9, 2021. The copyright holder for this preprint (which was not certified by peer review) is the author/funder, who has granted medRxiv a license to display the preprint in perpetuity.

It is made available under a CC-BY-NC-ND 4.0 International license .

state: a multicentre cohort study (SAM-COVID-19). Clin Microbiol Infect. 2020.

doi:10.1016/j.cmi.2020.08.010

16. Salvarani C, Dolci G, Massari M, Merlo DF, Cavuto S, Savoldi L, et al. Effect of

Tocilizumab vs Standard Care on Clinical Worsening in Patients Hospitalized with

COVID-19 Pneumonia: A Randomized Clinical Trial. JAMA Intern Med. 2020.

doi:10.1001/jamainternmed.2020.6615

17. Hermine O, Mariette X, Tharaux PL, Resche-Rigon M, Porcher R, Ravaud P. Effect of

Tocilizumab vs Usual Care in Adults Hospitalized with COVID-19 and Moderate or

Severe Pneumonia: A Randomized Clinical Trial. JAMA Intern Med. 2020; 1-9.

337 doi:10.1001/jamainternmed.2020.6820

18. Stone JH, Frigault MJ, Serling-Boyd NJ, Fernandes AD, Harvey L, Foulkes AS, et al.

Efficacy of Tocilizumab in Patients Hospitalized with Covid-19. N Engl J Med. 2020;

1-12. doi:10.1056/nejmoa2028836

19. Leaf DE, Gupta S, Wang W. Tocilizumab in Covid-19. N Engl J Med. 2021;384: 86-

87. doi:DOI: 10.1056/NEJMc2032911

20. Parr JB. Time to Reassess Tocilizumab's Role in COVID-19 Pneumonia. JAMA Intern

Med. 2020; 1-4. doi:10.1001/jamainternmed.2020.6557

21. Huang E, Jordan SC. Tocilizumab for Covid-19 — The Ongoing Search for Effective

Therapies. N Engl J Med. 2020;383: 2387-2388. doi:10.1056/nejme2032071

22. Rosas I, Bräu N, Waters M, Go R, Hunter B, Bhagani S, Skiest D, Aziz M, Cooper N, 
medRxiv preprint doi: https://doi.org/10.1101/2021.03.04.21252167; this version posted March 9, 2021. The copyright holder for this preprint (which was not certified by peer review) is the author/funder, who has granted medRxiv a license to display the preprint in perpetuity.

It is made available under a CC-BY-NC-ND 4.0 International license .

353 23. Salama C, Han J, Yau L, Reiss WG, Kramer B, Neidhart JD, et al. Tocilizumab in

354 Patients Hospitalized with Covid-19 Pneumonia. N Engl J Med. 2020.

355 doi:10.1056/nejmoa2030340

356

24. Anthony C. Gordon, Paul R. Mouncey, Farah Al-Beidh, Kathryn M. Rowan, Alistair

D. Nichol, Yaseen M. Arabi, Djillali Annane, Abi Beane, Wilma van Bentum-Puijk,

Lindsay R. Berry, Zahra Bhimani, Marc J.M. Bonten, Charlotte A. Bradbury, Frank M.

Brunkhorst, A LPGD. Interleukin-6 Receptor Antagonists in Critically Ill Patients with

362

25. RECOVERY Collaborative Group. Tocilizumab in patients admitted to hospital with

COVID-19 (RECOVERY): preliminary results of a randomised, controlled, open-label, platform trial. medRxiv:21249258 [preprint]. 2021 [cited 2021 February 21]. Available from: https://doi.org/10.1101/2021.02.11.21249258

26. Kim MS, An MH, Kim WJ, Hwang TH. Comparative efficacy and safety of pharmacological interventions for the treatment of COVID-19: A systematic review and network meta-analysis. PLoS Med. 2020;17: 1-28. doi:10.1371/journal.pmed.1003501

27. Characteristics IE. Diagnosis and Treatment Protocol for Novel Coronavirus Pneumonia (Trial Version 6, Revised). 2019.

28. Marshall JC, Murthy S, Diaz J, Adhikari N, Angus DC, Arabi YM, et al. A minimal common outcome measure set for COVID-19 clinical research. Lancet Infect Dis. 2020;20: e192-e197. doi:10.1016/S1473-3099(20)30483-7

29. Chen W-L, Lin W-T, Kung S-C, Lai C-C, Chao C-M. The Value of Oxygenation 
medRxiv preprint doi: https://doi.org/10.1101/2021.03.04.21252167; this version posted March 9, 2021. The copyright holder for this preprint (which was not certified by peer review) is the author/funder, who has granted medRxiv a license to display the preprint in perpetuity.

It is made available under a CC-BY-NC-ND 4.0 International license .

378 30. Wang D, Hu B, Hu C, Zhu F, Liu X, Zhang J, et al. Clinical Characteristics of 138

379 Hospitalized Patients with 2019 Novel Coronavirus-Infected Pneumonia in Wuhan,

China. JAMA - J Am Med Assoc. 2020;323: 1061-1069. doi:10.1001/jama.2020.1585

381

31. Goonasekera C, Peiris P, Oswald L, Sheikh A. SpO2: How Low is Too Low? J Med

382

Physiol Ther. 2017;1: 105-107. Available: https://www.omicsonline.org/open-

383

access/spo2-how-low-is-too-low.php?aid=93121

384

32. Roppolo LP, Wigginton JG. Preventing severe hypoxia during emergent intubation: Is nasopharyngeal oxygenation the answer? Crit Care. 2010;14. doi:10.1186/cc9197

33. Griesdale DEG, Bosma TL, Kurth T, Isac G, Chittock DR. Complications of endotracheal intubation in the critically ill. Intensive Care Med. 2008;34: 1835-1842. doi:10.1007/s00134-008-1205-6

34. Hernan MA, Robins JM (2020). Causal Inference: What If. Boca Raton: Chapman \& Hall/CRC.

35. Angel M, Brumback B, Robins JM. Marginal Structural Models to Estimate the Causal Effect of Zidovudine on the Survival of HIV-Positive. Epidemiology. 2000; 561-570.

36. Fewell Z, Hern MA, Wolfe F. Controlling for time-dependent confounding using marginal structural models. Stata J. 2004; 402-420.

37. Somers VK, Kara T, Xie J. Progressive Hypoxia: A Pivotal Pathophysiologic Mechanism of COVID-19 Pneumonia. Mayo Clin Proc. 2020/09/30. 2020;95: 2339_ 2342. doi:10.1016/j.mayocp.2020.09.015

38. Festic E, Bansal V, Kor DJ, Gajic O. SpO2/FiO2 ratio on hospital admission is an indicator of early acute respiratory distress syndrome development among patients at risk. J Intensive Care Med. 2015;30: 209-216. doi:10.1177/0885066613516411 
medRxiv preprint doi: https://doi.org/10.1101/2021.03.04.21252167; this version posted March 9, 2021. The copyright holder for this preprint (which was not certified by peer review) is the author/funder, who has granted medRxiv a license to display the preprint in perpetuity.

It is made available under a CC-BY-NC-ND 4.0 International license .

403

404

405

406

407

408

409

410

411

412

413

414

415

416

417

418

419

420

421

422

423

424

425

426

427

lung injury or ARDS. Chest. 2007;132: 410-417. doi:10.1378/chest.07-0617

40. Ranieri VM, Rubenfeld GD, Thompson BT, Ferguson ND, Caldwell E, Fan E, et al. Acute respiratory distress syndrome: The Berlin definition. JAMA - J Am Med Assoc. 2012;307: 2526-2533. doi:10.1001/jama.2012.5669

41. Lu X, Jiang L, Chen T, Wang Y, Zhang B, Hong Y, et al. Continuously available ratio of $\mathrm{SpO} 2 / \mathrm{FiO} 2$ serves as a noninvasive prognostic marker for intensive care patients with COVID-19. Respir Res. 2020;21: 1-4. doi:10.1186/s12931-020-01455-4

42. Xie J, Covassin N, Fan Z, Singh P, Gao W, Li G, et al. Association Between Hypoxemia and Mortality in Patients With COVID-19. Mayo Clin Proc. 2020;95: 1138-1147. doi:10.1016/j.mayocp.2020.04.006

43. Parr JB. Time to Reassess Tocilizumab's Role in COVID-19 Pneumonia. JAMA Intern Med. 2020; 1-4. doi:10.1001/jamainternmed.2020.6557

44. Furlow B. COVACTA trial raises questions about tocilizumab's benefit in COVID-19. Lancet Rheumatol. 2020;2: e592. doi:10.1016/s2665-9913(20)30313-1

45. Gupta S, Wang W, Hayek SS, Chan L, Mathews KS, Melamed ML, et al. Association Between Early Treatment With Tocilizumab and Mortality Among Critically Ill Patients With COVID-19. JAMA Intern Med. 2020;02115: 1-11. doi:10.1001/jamainternmed.2020.6252

46. Guaraldi G, Meschiari M, Cozzi-Lepri A, Milic J, Tonelli R, Menozzi M, et al. Tocilizumab in patients with severe COVID-19: a retrospective cohort study. Lancet Rheumatol. 2020;2: e474-e484. doi:10.1016/S2665-9913(20)30173-9

47. Price CC, Altice FL, Shyr Y, Koff A, Pischel L, Goshua G, et al. Tocilizumab Treatment for Cytokine Release Syndrome in Hospitalized Patients With Coronavirus Disease 2019: Survival and Clinical Outcomes. Chest. 2020;158: 1397-1408. doi:10.1016/j.chest.2020.06.006 
medRxiv preprint doi: https://doi.org/10.1101/2021.03.04.21252167; this version posted March 9, 2021. The copyright holder for this preprint (which was not certified by peer review) is the author/funder, who has granted medRxiv a license to display the preprint in perpetuity.

It is made available under a CC-BY-NC-ND 4.0 International license .

428 48. Somers EC, Eschenauer GA, Troost JP, Golob JL, Gandhi TN, Wang L, et al.

Tocilizumab for Treatment of Mechanically Ventilated Patients With COVID-19. Clin

430

Infect Dis. 2020. doi:10.1093/cid/ciaa954

431

49. F Hoffman-La Roche Ltd. Roche provides an update on the phase III COVACTA trial of Actemra/RoActemra in hospitalised patients with severe COVID-19 associated pneumonia. Published July 29, 2020. Accessed September 19, 2020. https://www.roche.com/investors/.

50. Salama C, Han J, Yau L, Reiss W, Kramer B, Neidhart J, Criner G, Kaplan-Lewis E, Baden R, Pandit L, Cameron M, Garcia-Diaz J, Chávez V, Mekebeb-Reuter M, Ferdinando $\square$; , Menezes L, Shah R, González-Lara M, Assman B, Freedman J, Mohan S, San $\square$; Associates J KL. Tocilizumab in nonventilated patients hospitalized with Covid-19 pneumonia. doi:https://doi.org/10.1101/2020.10.21.20210203 
medRxiv preprint doi: https://doi.org/10.1101/2021.03.04.21252167; this version posted March 9, 2021. The copyright holder for this preprint (which was not certified by peer review) is the author/funder, who has granted medRxiv a license to display the preprint in perpetuity.

It is made available under a CC-BY-NC-ND 4.0 International license .

\section{Table 1. Descriptive characteristics of the patient population}

\begin{tabular}{|c|c|c|c|}
\hline & Tocilizumab & $\begin{array}{l}\text { No } \\
\text { tocilizumab }\end{array}$ & $\mathbf{p}$ \\
\hline $\mathrm{N}$ (patients) & 167 & 327 & \\
\hline Age (years), mean $(\mathrm{SD})^{*}$ & $\begin{array}{l}66.24 \\
(11.38)\end{array}$ & $\begin{array}{l}66.93 \\
(15.76)\end{array}$ & 0.62 \\
\hline Gender (male) \% & 67.1 & 55 & 0.012 \\
\hline $\begin{array}{l}\text { Days between onset symptoms } \\
\text { and admission, } \\
\text { mean (SD)* }\end{array}$ & $7.29(4.88)$ & $6.74(5.62)$ & 0.262 \\
\hline \multicolumn{4}{|l|}{ Onset symptoms (\% of patients) } \\
\hline Fever & 91.2 & 85.3 & 0.078 \\
\hline Cough & 77.4 & 78.1 & 0.86 \\
\hline Throat pain & 5.8 & 7.7 & 0.46 \\
\hline Dyspnea & 72.6 & 65.2 & 0.12 \\
\hline Vomiting & 9.8 & 13 & 0.33 \\
\hline Diarrhea & 28.7 & 24 & 0.30 \\
\hline \multicolumn{4}{|l|}{ Comorbidities (\% of patients) } \\
\hline Cancer & 6.5 & 10.5 & 0.17 \\
\hline Diabetes & 27.4 & 23.8 & 0.42 \\
\hline Cardiac or cerebrovascular disease & 55.7 & 56.8 & 0.83 \\
\hline Chronic hepatitis & 3.8 & 3.7 & 0.95 \\
\hline COPD & 5.2 & 5.7 & 0.81 \\
\hline Chronic kidney disease & 7.1 & 9.8 & 0.34 \\
\hline Neurological disease & 8.3 & 12.2 & 0.22 \\
\hline \multicolumn{4}{|l|}{ Other treatments (\% of patients) } \\
\hline Interferon & 53.3 & 27.5 & $<0.001$ \\
\hline CRS (\% of patients) & & & $<0.001$ \\
\hline 1 & 26.9 & 88.6 & \\
\hline 2 & 53.9 & 8 & \\
\hline 3 & 19.2 & 3.4 & \\
\hline
\end{tabular}


Table 2. Baseline patient characteristics of CRS stages.

\begin{tabular}{llllllll}
\hline Characteristic & No. & CRS 1 & No. & CRS 2 & No. & CRS 3 & p value \\
\hline No. & 334 & & 116 & 105 & 44 & 37 & \\
\hline Age, mean (StDev) & 334 & 65.7 & 116 & 68.6 & 44 & 68.9 & $* \mathrm{p}=0.1053$ \\
& & $(15.3)$ & & $(12.7)$ & & $(11.1)$ & \\
\hline Male, No./No. (\%) & 333 & $185 / 333$ & 116 & $76 / 116$ & 43 & $29 / 43$ & \\
& & $(55.6 \%)$ & & $(65.5 \%)$ & & $(67.4 \%)$ & \\
\hline Female, No./No. (\%) & 333 & $148 / 333$ & 116 & $40 / 116$ & 43 & $14 / 43$ & $* * \mathrm{p}=0.085$ \\
& & $(44.4 \%)$ & & $(34.5 \%)$ & & $(32.6 \%)$ & \\
& & & & & &
\end{tabular}

\section{Comorbidities,}

No./No. $(\%)$

\begin{tabular}{|c|c|c|c|c|c|c|c|}
\hline - Cancer & 256 & $\begin{array}{l}25 / 256 \\
(9.8 \%)\end{array}$ & 101 & $\begin{array}{l}9 / 101 \\
(8.9 \%)\end{array}$ & 33 & $\begin{array}{l}0 / 33 \\
(0.0 \%)\end{array}$ & $* * p=0.17$ \\
\hline - Diabetes & 266 & $\begin{array}{l}68 / 266 \\
(25.6 \%)\end{array}$ & 102 & $\begin{array}{l}23 / 102 \\
(22.5 \%)\end{array}$ & 35 & $\begin{array}{l}10 / 35 \\
(28.6 \%)\end{array}$ & $* * p=0.74$ \\
\hline $\begin{array}{l}\text { - Cardiovascular } \\
\text { disease }\end{array}$ & 269 & $\begin{array}{l}153 / 269 \\
(56.9 \%)\end{array}$ & 102 & $\begin{array}{l}54 / 102 \\
(52.9 \%)\end{array}$ & 35 & $\begin{array}{l}21 / 35 \\
(60.0 \%)\end{array}$ & $* * \mathrm{p}=0.71$ \\
\hline - Chronic hepatitis & 261 & $\begin{array}{l}12 / 261 \\
(4.6 \%)\end{array}$ & 100 & $\begin{array}{l}1 / 100 \\
(1.0 \%)\end{array}$ & 35 & $\begin{array}{l}2 / 35 \\
(5.7 \%)\end{array}$ & $* * p=0.23$ \\
\hline - EPOC & 262 & $\begin{array}{l}13 / 262 \\
(5.0 \%)\end{array}$ & 100 & $\begin{array}{l}8 / 100 \\
(8.0 \%)\end{array}$ & 35 & $\begin{array}{l}0 / 35 \\
(0.0 \%)\end{array}$ & $* * p=0.18$ \\
\hline $\begin{array}{l}\text { - Chronic kidney } \\
\text { disease }\end{array}$ & 262 & $\begin{array}{l}21 / 262 \\
(8.0 \%)\end{array}$ & 101 & $\begin{array}{l}10 / 101 \\
(9.9 \%)\end{array}$ & 35 & $\begin{array}{l}3 / 35 \\
(8.6 \%)\end{array}$ & $* * p=0.85$ \\
\hline $\begin{array}{l}\text { - Neurological } \\
\text { disease }\end{array}$ & 264 & $\begin{array}{l}29 / 264 \\
(11.0 \%)\end{array}$ & 100 & $\begin{array}{l}10 / 100 \\
(10.0 \%)\end{array}$ & 35 & $\begin{array}{l}2 / 35 \\
(5.7 \%)\end{array}$ & $* * \mathrm{p}=0.62$ \\
\hline - Immunodeficiency & 255 & $\begin{array}{l}20 / 255 \\
(7.8 \%)\end{array}$ & 98 & $\begin{array}{l}11 / 98 \\
(11.2 \%)\end{array}$ & 33 & $\begin{array}{l}0 / 33 \\
(0 / 0 \%)\end{array}$ & $* * p=0.12$ \\
\hline $\mathrm{SpO}_{2}$ limits & 334 & $\geq 93$ & 116 & $\begin{array}{l}\geq 89.5 \\
\text { and }<94\end{array}$ & 44 & $\leq 83,5$ & \\
\hline $\mathrm{FiO}_{2}$ & 334 & $0.35 \leq$ & & 0.5 & & $\begin{array}{l}0.5 \\
\text { or MV }\end{array}$ & \\
\hline $\begin{array}{l}\mathrm{SpO}_{2}: \mathrm{FiO}_{2}, \quad \text { median } \\
\text { (IQR) }\end{array}$ & 334 & $>265$ & 116 & $\begin{array}{l}>179 \text { and } \\
<188\end{array}$ & 44 & $<167$ & \\
\hline $\begin{array}{l}\mathrm{PaO}_{2}: \mathrm{FiO}_{2}, \quad \text { median } \\
(\mathrm{IQR})\end{array}$ & 334 & $>240$ & 116 & $\begin{array}{l}>136 \text { and } \\
<148\end{array}$ & 44 & $<123$ & \\
\hline
\end{tabular}


medRxiv preprint doi: https://doi.org/10.1101/2021.03.04.21252167; this version posted March 9, 2021. The copyright holder for this preprint (which was not certified by peer review) is the author/funder, who has granted medRxiv a license to display the preprint in perpetuity.

\section{It is made available under a CC-BY-NC-ND 4.0 International license .}

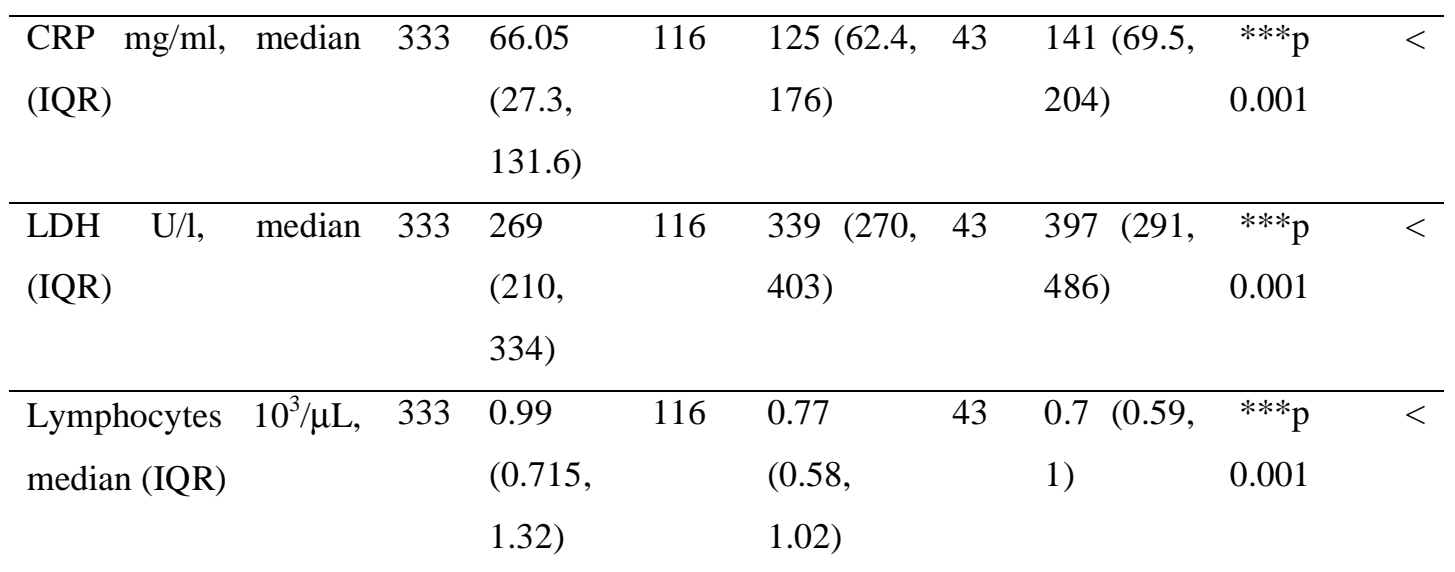

*ANOVA, **Pearson's Chi-squared test, ***Kruskal Wallis. $\mathrm{PaO}_{2}: \mathrm{FiO}_{2}$ ratio was estimated from $\mathrm{SpO}_{2}: \mathrm{FiO}_{2}$ (ref. 32). 
medRxiv preprint doi: https://doi.org/10.1101/2021.03.04.21252167; this version posted March 9, 2021. The copyright holder for this preprint (which was not certified by peer review) is the author/funder, who has granted medRxiv a license to display the preprint in perpetuity.

It is made available under a CC-BY-NC-ND 4.0 International license.

Table 3. Multivariate regression models to estimate the effect of tocilizumab adjusted for the CRS stages.

\begin{tabular}{|c|c|c|c|c|c|c|c|c|c|c|c|}
\hline & \multicolumn{4}{|c|}{ Model 1} & \multicolumn{4}{|c|}{ Model 2} & \multicolumn{3}{|c|}{ Model 3} \\
\hline & HR & {$\left[95^{\circ}\right.$} & $\% \mathrm{CI}]$ & $\mathrm{p}$ & HR & {$[95 \%$} & $\mathrm{CI}]$ & $\mathrm{P}$ & HR & {$[95 \% \mathrm{CI}]$} & $\mathrm{p}$ \\
\hline Tocilizumab & 0.42 & 0.26 & 0.66 & $<0.001$ & 0.22 & 0.09 & 0.59 & 0.002 & 0.17 & $\begin{array}{lll}0.06 & 0.47\end{array}$ & $<0.001$ \\
\hline Age (years) & 1.03 & 1.01 & 1.04 & $<0.001$ & 1.02 & 1.00 & 1.04 & 0.023 & 1.03 & 1.001 .05 & 0.020 \\
\hline Sex (male) & 1.26 & 0.90 & 1.76 & 0.183 & 1.19 & 0.75 & 1.91 & 0.46 & 1.53 & 0.912 .59 & 0.107 \\
\hline CRS & - & & & & - & & & & - & & \\
\hline 2 & 2.80 & 1.75 & 4.47 & $<0.001$ & 8.45 & 4.40 & 16.22 & $<0.001$ & 10.42 & $5.23 \quad 20.76$ & $<0.001$ \\
\hline 3 & 12.75 & 7.65 & 21.23 & $<0.001$ & 23.14 & 12.83 & 41.74 & $<0.001$ & 27.23 & $1.47 \quad 64.66$ & $<0.001$ \\
\hline $\begin{array}{l}\text { Other } \\
\text { treatments: } \\
\text { Interferon }\end{array}$ & 1.87 & 1.33 & 2.62 & 0.001 & 1.21 & 0.75 & 1.95 & 0.428 & 1.55 & $0.91 \quad 2.64$ & 0.108 \\
\hline
\end{tabular}




\section{Figure legends.}

Figure 1. Selection of patient groups for tocilizumab treatment.

Figure 2. (A) Kaplan-Meier estimation of clinical improvement in CRS1, CRS2 and CRS3 patients. Multivariate Cox regression analysis; $\mathrm{p}=0.334(\mathrm{CRS} 1) ; \mathrm{p}<0.001(\mathrm{CRS} 2) ; \mathrm{p}=0.018$ (CRS3). (B) Numbers and proportions of tocilizumab treated and untreated patients that reached the outcome; Pearson's chi-square test.

Figure 3. Increased probability of survival after tocilizumab treatment. Survival corresponds to improvement of the end event defined as death or ICU admission. HR values correspond to multivariate Cox regression analysis. (A) Adjusted for age, sex, comorbidities, other treatments and CRS stages, as in Table 3 (model 1); (B) Adjusted as in (A) but not for CRS stages. 
medRxiv preprint doi: https://doi.org/10.1101/2021.03.04.21252167; this version posted March 9, 2021. The copyright holder for this preprint (which was not certified by peer review) is the author/funder, who has granted medRxiv a license to display the preprint in perpetuity.

\section{It is made available under a CC-BY-NC-ND 4.0 International license .}

\section{Figure 1}

RT-PCR

3,219 patients

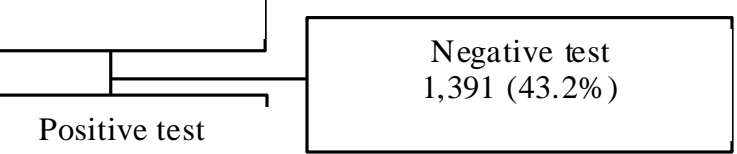

$1,828(56.8 \%)$

Home care 1,153 (64.3\%)

Missing $39(2.2 \%)$

Hospitalized

$600(33.5 \%)$

Not eligible for protocol

$75(12.5 \%)$

Followed

protocol

$525(87.5 \%)$

Study

$494(94.1 \%)$

Follow up $<24$ hours

7 ICU admissions

8 hospital discharge

11 deaths

5 transfer to other hospital

Tocilizumab

$167(33.8 \%)$

No to cilizumab

$327(66.2 \%)$ 
medRxiv preprint doi: https://doi.org/10.1101/2021.03.04.21252167; this version posted March 9, 2021. The copyright holder for this preprint (which was not certified by peer review) is the author/funder, who has granted medRxiv a license to display the preprint in perpetuity.

It is made available under a CC-BY-NC-ND 4.0 International license.

\section{Figure 2}

A

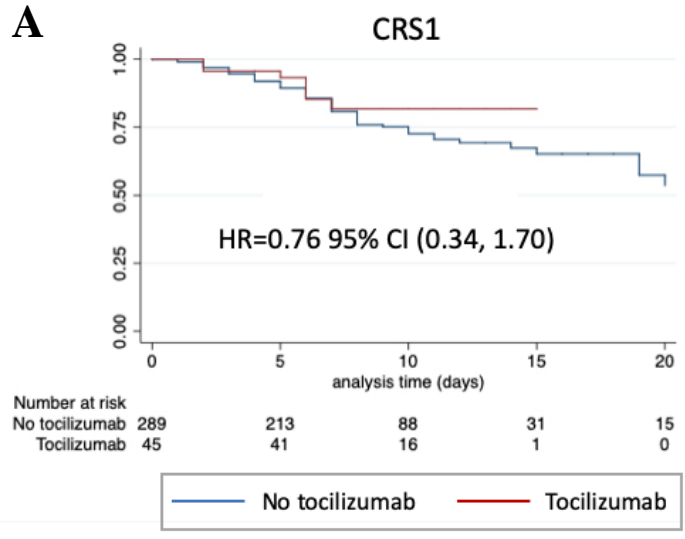

CRS3

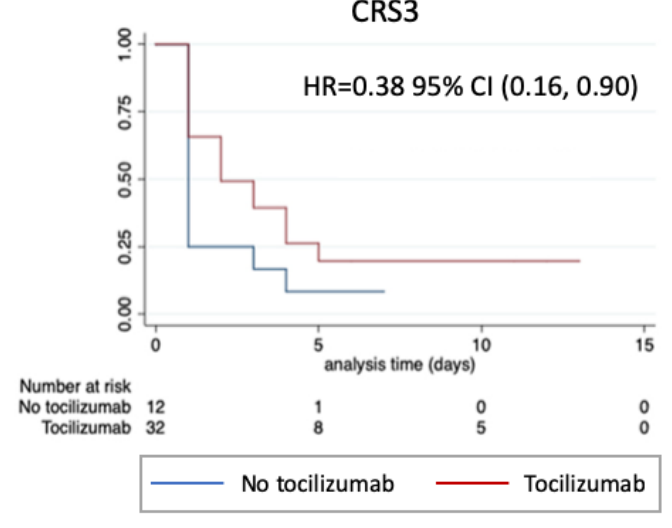

CRS2

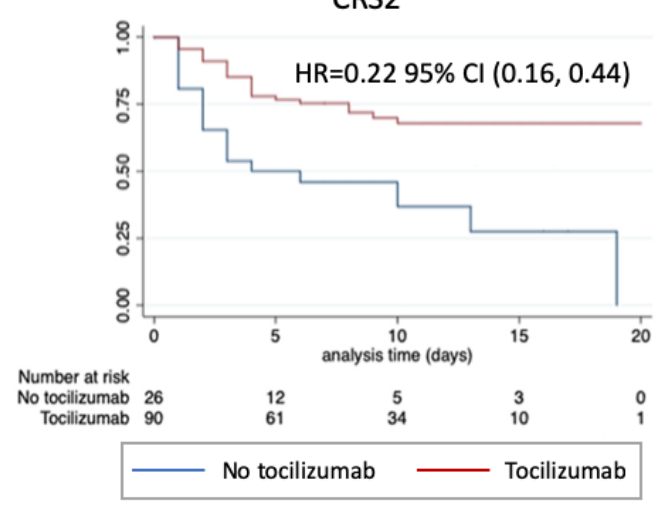

B

\begin{tabular}{llllll}
\hline Total $(\mathrm{n}=494)$ & \multicolumn{2}{l}{ Tocilizumab $(\mathrm{n}=167)$} & \multicolumn{2}{l}{ No tocilizumab $(\mathrm{n}=327)$} & $\mathrm{p}$ value \\
\hline & $\mathrm{n}$ & Outcome & $\mathrm{n}$ & Outcome & \\
\hline CRS1 $(\mathrm{n}=334)$ & 45 & $7(15.6 \%)$ & 289 & $68(23.5 \%)$ & 0.233 \\
\hline CRS2 $(\mathrm{n}=116)$ & 90 & $25(27.8 \%)$ & 26 & $17(65.4 \%)$ & $<0.001$ \\
\hline CRS3 $(\mathrm{n}=44)$ & 32 & $25(78.1 \%)$ & 12 & $11(91.6 \%)$ & 0.413 \\
\hline Pearson's chi-square test & & & & &
\end{tabular}


medRxiv preprint doi: https://doi.org/10.1101/2021.03.04.21252167; this version posted March 9, 2021. The copyright holder for this preprint (which was not certified by peer review) is the author/funder, who has granted medRxiv a license to display the preprint in perpetuity.

\section{It is made available under a CC-BY-NC-ND 4.0 International license .}

\section{Figure 3}

A

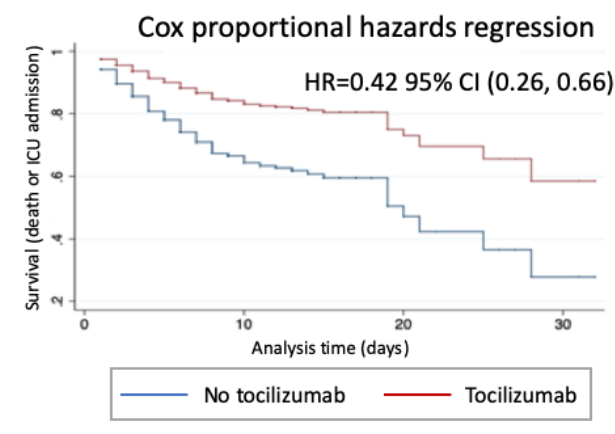

B

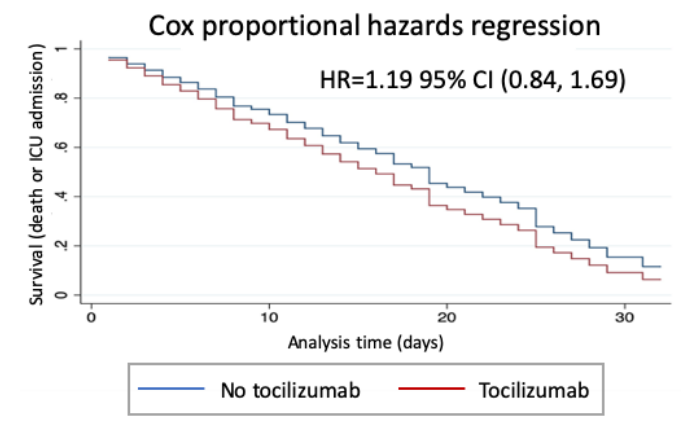


medRxiv preprint doi: https://doi.org/10.1101/2021.03.04.21252167; this version posted March 9, 2021. The copyright holder for this preprint (which was not certified by peer review) is the author/funder, who has granted medRxiv a license to display the preprint in perpetuity.

\author{
It is made available under a CC-BY-NC-ND 4.0 International license.
}

